\title{
Estimating the ashfall volume for a small eruption using ellipse-approximated isopach analysis: how many seeking points are required to determine a suitable axis?
}

\author{
Yasuhisa Tajima* (1)
}

\begin{abstract}
A volcanic ash eruption began on March 1,2018, and a lava flow was observed on March 6 at Shinmoedake volcano in the Kirishima Volcano Group. The small ash eruptions continued until June 27, 2018. The amounts of volcanic ashfall around Shinmoedake volcano from these eruptions were observed, and the volcanic ashfall distributions for each eruptions were analyzed. However, many cases of small eruptions were insufficient observation points to determine the ashfall volumes. Therefore, the ellipse-approximated isopach (EAI) method was used. However, the EAI method requires verification seeking points to determine an angle of a calculation axis including two calculation points to perform the analysis. Fortunately, adequate wind conditions enabled the observation of ashfall amount values at some locations after one eruption on June 27,2018. And the EAl analysis was conducted to determine this ashfall distribution using 1-4 seeking points. As a result, it is considered that a suitable axis requires three seeking points to determine the EAl distribution.
\end{abstract}

Keywords: Kirishima Volcano Group, Shinmoedake, Ashfall, Volume, Small eruption

\section{Introduction}

Shinmoedake volcano in the Kirishima Volcano Group (Fig. 1) has undergone repeated magmatic eruptions and quiet periods lasting hundreds to thousands of years and is currently in an active magmatic eruption period (Tajima et al. 2013a). Subplinian eruptions were produced in 1716-1717 and 2011 (Imura and Kobayashi 1991; Nakada et al. 2013). The recent activities were small ash-producing eruptions from October 11-17, 2017. And a lava eruption from March 6 occurred in 2018 with small ash-producing eruptions from March 1 before the lava producing and Vulcanian or small eruptions until June 27 after the lava producing. Small volumes of volcanic ash were emitted before the 2011 subplinian eruptions

*Correspondence: yasuhisa79@gmail.com

Research \& Development Center, Nippon Koei Co., Ltd., 2304, Inarihara, Tsukuba, Japan and the 2018 lava eruption. Therefore, rapid and accurate determination of the volumes of volcanic ash produced by small eruptions before a peak magmatic eruption is an important framework for future monitoring. Additionally, the sequence of frequent Vulcanian or small eruptions after a peak magmatic eruption is indispensable for predicting the end of activity.

Several volume assessment methods for estimating of tephra using isopach have been proposed. The tephra volume is estimated using isopach in a plot of the layer thickness as $\log (T)$ against the area as $\log (A)$ of the deposit (Rose et al. 1973). Furthermore, an exponentially decreasing plot of $\log (T)$ against a simply square root of the area $\sqrt{ } A$ is used for larger tephra (Pyle 1989). Two proximal and distal exponential rates $(\mathrm{\kappa})$ of the plot of $\log (T)$ against $\sqrt{ } A$, which change at the break in the slope, have been used to calculate the volume (Fierstein and Nathenson 1992). A power method using a plot of 


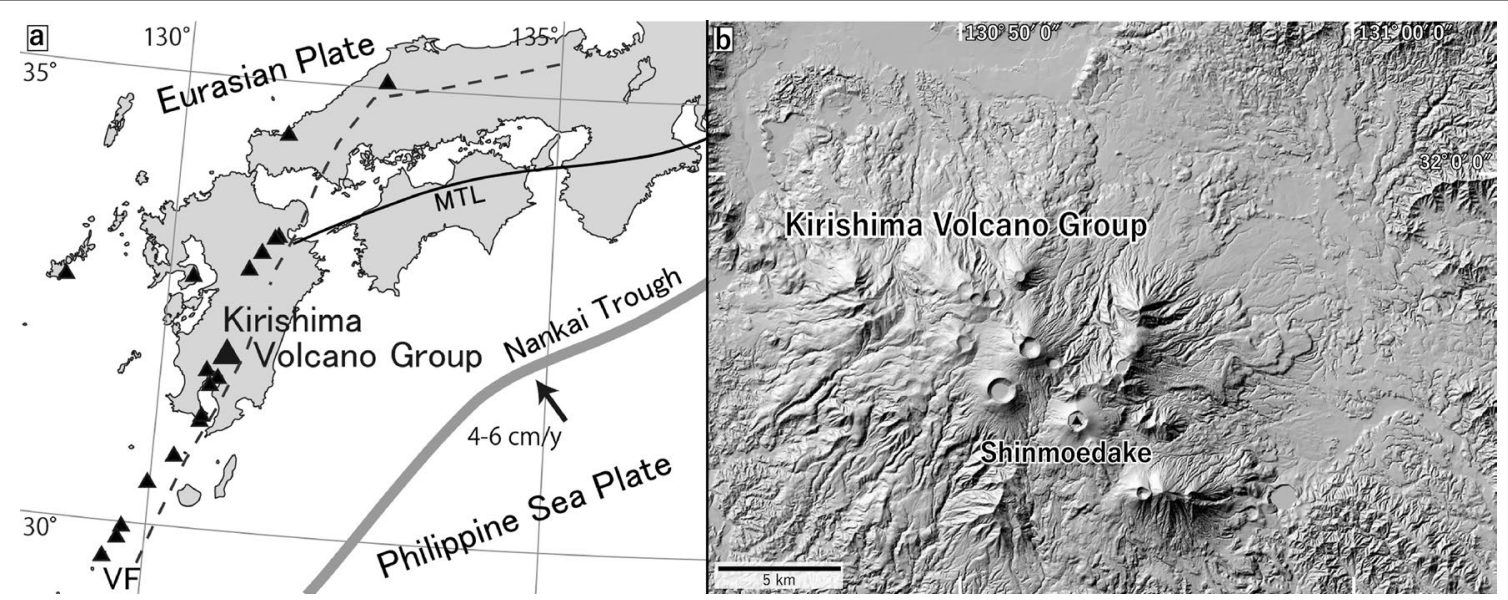

Fig. 1 Location index map of the Kirishima Volcano Group. a Index map of western Japan. VF: volcanic front. MTL: median tectonic line fault zone. $\mathbf{b}$ Shading relief map of the Kirishima Volcano Group obtained using the website of the Geospatial Information Authority of Japan

$\log (\mathrm{T})$ against $\sqrt{ } \mathrm{A}$ was used to estimate the volume of the tephra (Bonadonna and Houghton 2005). The volume/mass of the ashfall can be calculated by segment integration, which introduces segments to a thickness/ weight-area plot (Takarada et al. 2001; Takarada et al. 2002; Takarada et al. 2016). The Weibull distribution has recently been proposed as a method for estimating tephra volume (Bonadonna and Costa 2012, 2013). However, many isolines of an isopach or ashfall amounts are required to accurately estimate the tephra or ashfall volume over large areas when using such methods. Meanwhile, obtaining the volume from a single isoline has also been proposed (Hayakawa 1985). The equation is $V=12.2 \mathrm{TA}$, which is approximately based on the tephra volumes obtained by Walker (1980, 1981). Additionally, the following fixed equation has been proposed for the minimum volume obtained using some tephra isolines as $\mathrm{V}=3.69 \mathrm{TA}$ (Legros, 2000).

Tajima et al. (2013b) combined the concepts of the decay rate of the thickness of the ashfall layer with an increasing area approximated as the power of -1 (Aramaki and Hayakawa 1982) and the ash distribution approximated as elliptical shape (Pyle 1989; Bursik et al. 1992; Sulpizio 2005). They argued that the mass of a volcanic ash deposit could be estimated with two observation points and an accurate distribution (calculation) axis by assuming an ellipse similar to the ellipse-approximated isopach (EAI) method (Tajima et al. 2013b). Additionally, ashfall verification values called "seeking points" have been adopted to determine the calculation axis in the EAI method. However, discussions on the required number of seeking points are limited. In this study, the amounts of ashfall from the June 27, 2018 eruption were observed to determine the number of points required to accurately estimate the calculation axis. Changing the number of seeking points produced variable ashfall distributions and the resulting variations indicated an appropriate number of seeking points.

\section{The June $\mathbf{2 7}$ eruption and sample collection}

A small eruption occurred at Shinmoedake volcano at 15:34 Japan Standard Time (JST) on June 27, 2018. The column color was gray-white with a height of $2200 \mathrm{~m}$, according to records from the Japan Meteorological Agency (Japan Meteorological Agency 2018). The eruption column passed over the office in the town of Takaharu, according to the live camera image captured by UMK TV Miyazaki, and volcanic ash fell in central Takaharu east-northeast of Shinmoedake volcano (Fig. 2).

The ashfall distribution of the June 27 eruption was surveyed between June 28 and June 29, and volcanic ash was sampled as follows. Areas with minimal wind-sweeping were selected, because wind sometimes removes volcanic ash. For volcanic ash collection, sampling areas, such as park benches, facility concretes, public dust boxes, mail posts, and the outdoor units of air conditioners, were not in contact with the ground. A folding ruler was used to measure a square sampling area, and volcanic ash was placed into a sample bag using a dustpan and a brush. Volcanic ash at a monitoring point installed in the ashfall area was sampled in a small, clear plastic cup (Additional file 1: Table S1). Furthermore, the amount of volcanic ash was recorded under the following categories: abundant $(++)$, normal $(+)$, faint $(-)$, and not detected (nd) when not sampled (e.g., on leaves). A Garmin handheld GPS or a digital camera equipped with a GPS function was used to measure the latitude and longitude at the observation points. The weights of the dried samples were measured 


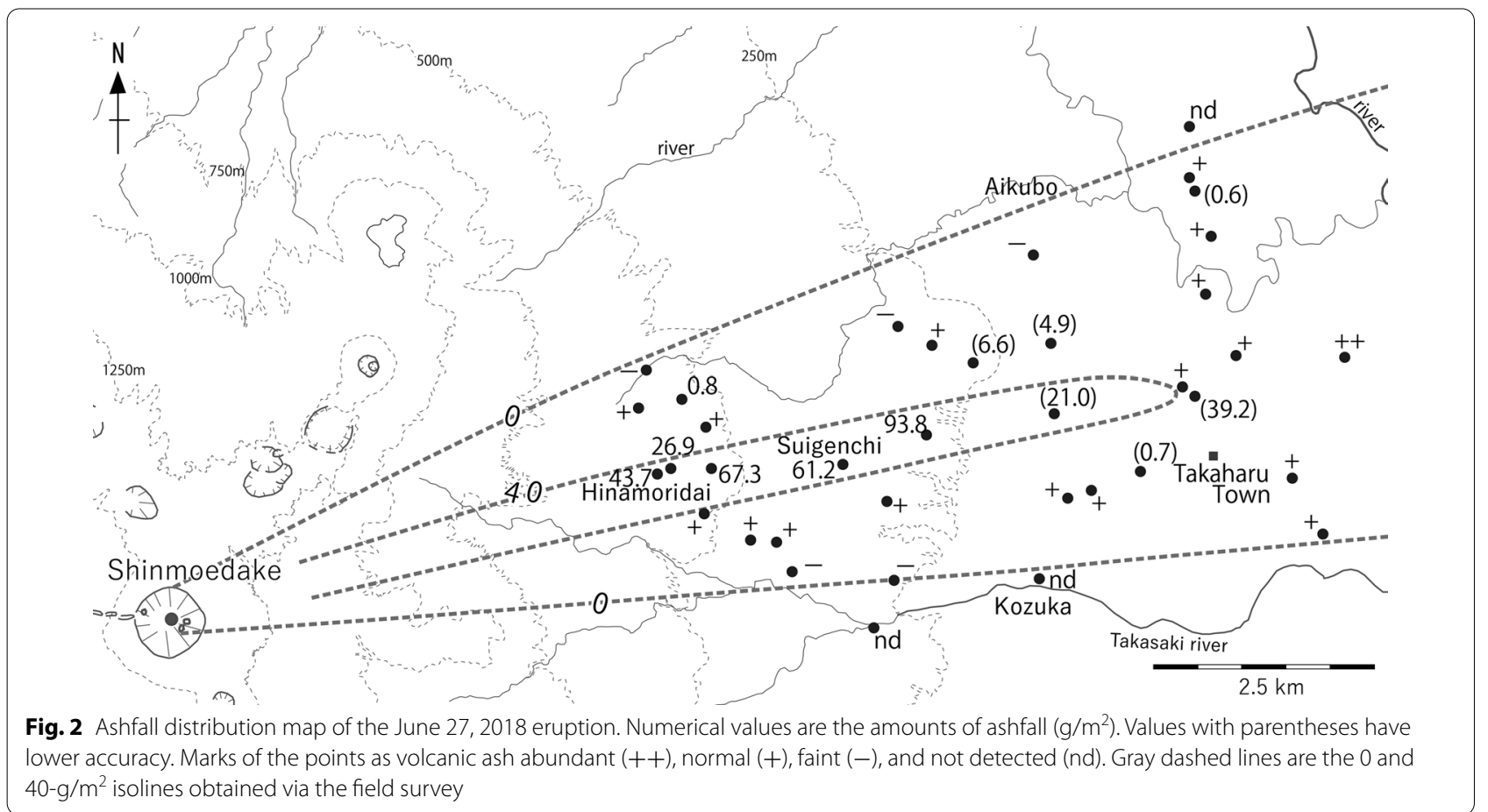

and converted into the ashfall amount $\left(\mathrm{g} / \mathrm{m}^{2}\right)$ of the collection area.

In the field survey, the amounts of ashfall exceeded $60 \mathrm{~g} / \mathrm{m}^{2}$ at Hinamoridai and Suigenchi (Fig. 2). The southern limit of the ashfall distribution was in Kozuka, near the Takasaki River and the northern limit was in Aikubo. The gray break lines indicate the ashfall distribution limits and the isoline of $40 \mathrm{~g} / \mathrm{m}^{2}$. Accretionary lapilli were approximately $1 \mathrm{~mm}$ in diameter at the Suigenchi $\left(61.2 \mathrm{~g} / \mathrm{m}^{2}\right)$ point. No rainfall was registered in central Takaharu during the ashfall, but weak rainfall in Hinamoridai reported in the interview might have fallen in the mountainous area. Ash particles were divided five types as black glass with sometimes drop-like shapes (14\%), gray glass fragments with fresh and sharp shapes (56\%), red fragments with sharp shapes (13\%), plagioclase (11\%), and pyroxenes (5\%) (Additional file 4: Fig. S1). In addition, microscopic observations revealed that some red fragments had secondary minerals and rounded shapes. Ash particles were smaller than $2 \mathrm{~mm}$ in diameter in the observed area (Additional file 4: Fig. S1). This was not significantly different from those of the 2011 vulcanian or small eruptions (Suzuki et al. 2013).

\section{EAI analysis method}

The EAI analysis is a volume (mass) estimation tool for an ashfall deposit that sets four conditions, including the fixed crater/vent location $\left(P_{0}\right)$, observation point
$1\left(P_{1}\right)$, observation point $2\left(P_{2}\right)$, and a calculation axis (Fig. 3; Tajima et al. 2013b). The vent location of this eruption was set at $31.911598^{\circ} \mathrm{N}, 130.882959^{\circ} \mathrm{E}$ based on the 2018 lava production center observed by the Geospatial Information Authority of Japan (2018) on April 1, 2018. This value was converted into a point on a rectangular coordinate system using the GSI website (Kawase 2011; Geospatial Information Authority of Japan 2013). The latitudes and longitudes of the observation points were also converted into rectangular coordinate system values, which were plotted on a coordinate system as an abscissa ( $x$ ) of east positive and an ordinate $(y)$ of north positive from an origin $P_{0}$ $(0,0)$ representing the vent location. The EAI method requires that the two observation points introduce similar ellipses with a same axis. The ellipses 1 and 2 were assigned to observation points $P_{1}\left(x_{1}, y_{1}\right)$ and $P_{2}\left(x_{2}, y_{2}\right)$, respectively. $T_{1}$ and $T_{2}$ are the thicknesses of $P_{1}$ and $P_{2}$, respectively. The locations of $P_{0}, P_{1}$, and $P_{2}^{\prime}$ on the ellipse 1 were calculated as follows:

$$
P_{0}=(0,0), P_{1}=\left(x_{1}, y_{1}\right), P_{2}^{\prime}=\left(\sqrt{\frac{T_{2}}{T_{1}}} x_{2}, \sqrt{\frac{T_{2}}{T_{1}}} y_{2}\right) .
$$

$P_{2}{ }^{\prime}$ is a converted equivalent value of $P_{2}$ on the ellipse 1. The major calculation $\left(a_{1}\right)$ and minor orthogonal $\left(b_{1}\right)$ axes lengths of the ellipse 1 can be calculated as follows: 


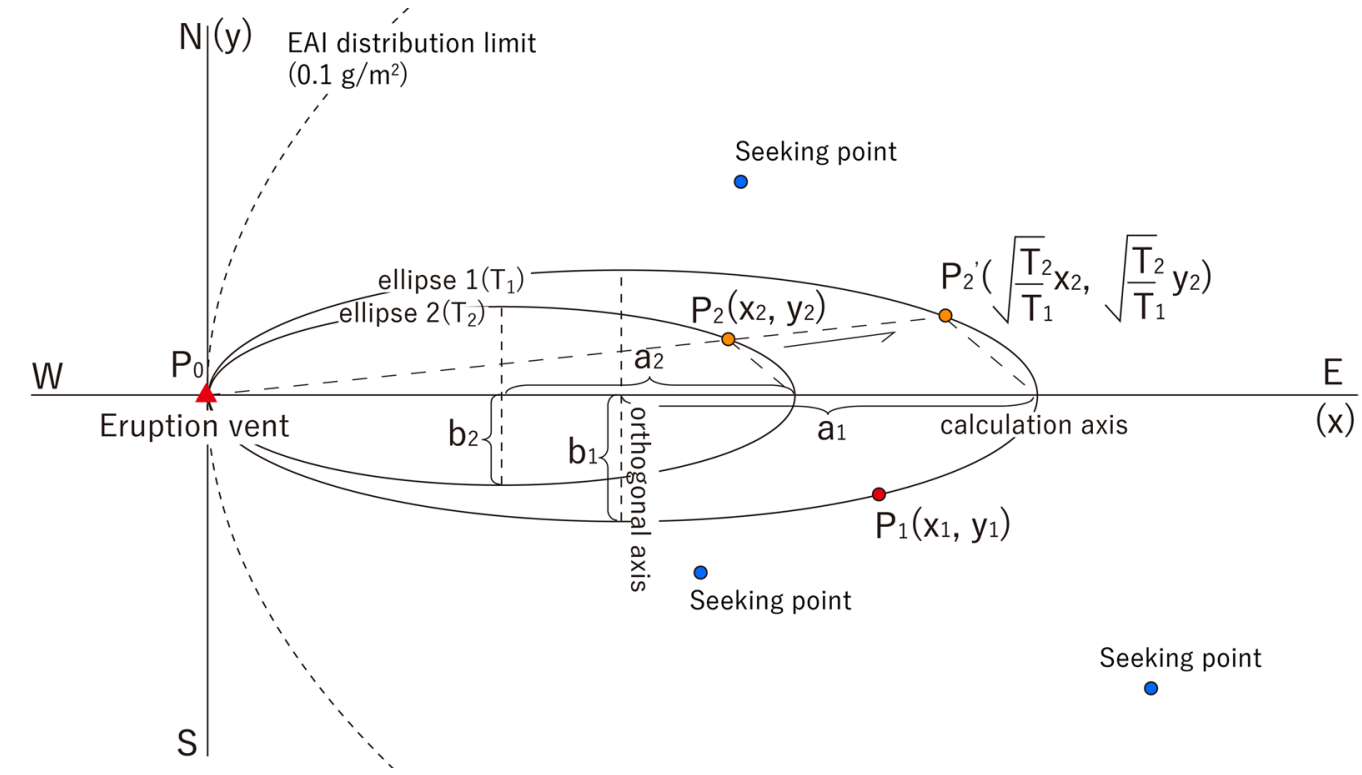

Fig. 3 Conceptional model of the ellipse-approximated isopach (EAI) analysis modified from Tajima et al. (2013b). Details are provided in the "EAI analysis method" section

$$
a_{1}=\frac{x_{1}^{2} y_{2}^{2}-x_{2}^{2} y_{1}^{2}}{2\left(x_{1} y_{2}^{2}-\sqrt{\frac{T_{1}}{T_{2}}} x_{2} y_{1}^{2}\right)}, b_{1}=\sqrt{\frac{a_{1}^{2} y_{1}^{2}}{2 a_{1} x_{1}-x_{1}^{2}}} .
$$

The ashfall volume was calculated as the area $(A)$ and volume $(V)$ using the following equation to fix from Tajima et al. (2013b):

$$
T=\alpha A^{-1} \text {. }
$$

The volume integral is:

$$
V=\int_{m}^{n} T d A=\int_{m}^{n} \alpha A^{-1} d A .
$$

The constant value $\alpha$ is obtained from the area and thickness. The minimum integral range area value $(m)$ is $10,000 \mathrm{~m}^{2}$ (Takarada et al. 2001). The maximum integral range area value $(n)$ is an area surrounded by an isoline of $0.1 \mathrm{~g} / \mathrm{m}^{2}$ given by the elliptical area formula using the axis length calculated according to Eq. 7 in Tajima et al. (2013b) and the elliptical aspect ratio. The maximum area of thickness $\left(0.1 \mathrm{~g} / \mathrm{m}^{2}\right)$ is based on observations of a very small eruption in the Sakurajima volcano (Tajima et al. 2013b). The amount of ashfall (g/ $\mathrm{m}^{2}$ ) was converted into a thickness of $1 \mathrm{~g} / \mathrm{cm}^{3}$ based on the densities of ashfall deposit from the small eruption on January 19, 2011 at Shinmoedake volcano (Additional file 2: Table S2). The reliable deposit densities of volcanic ashfall of the small eruption on January 19 are 0.7 to $1.0 \mathrm{~g} / \mathrm{cm}^{3}$. The ashfall deposit density $1.5 \mathrm{~g} /$ $\mathrm{cm}^{3}$ was used in Tajima et al. (2013b), but that sampling ashfall deposit was affected by slight compaction due to the time elapsed. In this study, the ashfall deposit density $1 \mathrm{~g} / \mathrm{cm}^{3}$ is considered as the represented value from those observation values.

The goal of this study is to determine the number of seeking points required to obtain an accurate calculation axis. Thus, we examined the following. First, observation points $\left(67.3,61.2,93.8\right.$, and $\left.43.7 \mathrm{~g} / \mathrm{m}^{2}\right)$ that were less affected by weather and sampling error were selected for calculation (Fig. 2). The values contained in parentheses in Fig. 2 were only used as supporting values, as they might have been affected by the bending column or wind. Two calculation points were chosen from the above the four observation points and a preliminary calculation axis was set based on the entire distribution. The insufficiency of the previous article (Tajima et al. 2013b) is the incomplete discussion regarding how to choose seeking points for a determined axis. Therefore, cases of one, two, three, or four seeking points were examined for verification. The following seeking points were used the observation point results at $67.3,61.2,26.9,43.7,93.8$, and $0.8 \mathrm{~g} /$ $\mathrm{m}^{2}$. The analysis of the number of seeking points cases calculated 24, 36, 24, and 6 combinations were obtained with one, two, three, and four seeking points excluded two calculation points, respectively. An optimal solution (determined axis) was eventually defined as the minimum value of the sum of (Obs./Cal. -1$)^{2}$ for the amounts of ashfall for an axis of $0.1^{\circ}$. A value "Obs." is 
an observed volcanic ashfall amount $\left(\mathrm{g} / \mathrm{m}^{2}\right)$, and a value "Cal." is a volcanic ashfall amount $\left(\mathrm{g} / \mathrm{m}^{2}\right)$ calculated by the EAI method. The ashfall distribution derived by the EAI method was defined as the EAI distribution, and the volume (mass) was called the EAI ashfall volume $\left(\mathrm{m}^{3}\right)$, or mass $(\mathrm{t})$.

\section{Results}

The EAI distributions were calculated by the EAI analysis for 1-4 seeking points. And the angle of the determined axis, ellipse aspect ratio (half radius of the orthogonal/ calculation axes), and the EAI volume were obtained for every calculation result (Additional file 3: Table S3). The EAI volumes were reported with three significant figures. The angle of the calculation axis ranged from $0^{\circ}$ to $360^{\circ}$ clockwise, starting from the east. Maximum, average close, and minimum examples of the EAI volumes (distributions) of each seeking points cases were obtained (Fig. 4). And the calculation limit of the EAI distribution (indicated by the gray dashed line in Fig. 4) was $0.1 \mathrm{~g} /$ $\mathrm{m}^{2}$, based on Tajima et al. (2013b). The mean value and standard deviation of the EAI volume were estimated for each seeking points cases using the probability density distribution (Fig. 5).

For the 24 one-point seeking calculations, the average axis angle was $345.9^{\circ}$, and the maximum-minimum angle difference was $2.8^{\circ}$. The average ellipse aspect ratio was 0.042 and ranged from 0.026 to 0.057 . The average EAI volume was $2.96 \times 10^{3} \mathrm{~m}^{3}$ and ranged from $0.68 \times 10^{3}$ to $4.74 \times 10^{3} \mathrm{~m}^{3}$. The standard deviation of the EAI volume was $0.93 \times 10^{3} \mathrm{~m}^{3}$, based on the one-point seeking calculations (Fig. 5). The EAI distribution limit was narrower than the observed distribution limit of the minimum EAI volume result, which was consistent with the smaller ellipse aspect ratio (Fig. 4a(1)). The EAI and observation distribution limits were similar to the result of average close EAI volume (Fig. 4a(2)). However, the EAI distribution limit was wider than the observed distribution limit of the maximum EAI volume result (Fig. $4 \mathrm{a}(3)$ ).

For the 36 two-point seeking calculations, the average axis angle was $345.9^{\circ}$, and the maximum-minimum angle difference was $1.6^{\circ}$. The average ellipse aspect ratio was 0.043 and ranged from 0.034 to 0.056 . The average EAI volume was $2.76 \times 10^{3} \mathrm{~m}^{3}$ and ranged from $1.62 \times 10^{3}$ to $4.44 \times 10^{3} \mathrm{~m}^{3}$. The standard deviation of the EAI volume was $0.49 \times 10^{3} \mathrm{~m}^{3}$ (Fig. 5). The distribution limit of the minimum EAI volume result was almost consistent with the observation result, but the $40 \mathrm{~g} / \mathrm{m}^{2}$ isoline axis of the EAI distribution was shorter (Fig. $4 \mathrm{~b}(1)$ ). The EAI distribution limit of the average close EAI volume result was consistent with the observation (Fig. $4 \mathrm{~b}(2)$ ). The EAI distribution limit of the maximum EAI volume result was wider than that of the observation result (Fig. 4b(3)).
For the 24 three-point seeking calculations, the average axis angle was $345.8^{\circ}$, and the maximum-minimum angle difference was $0.7^{\circ}$. The average ellipse aspect ratio was 0.043 and ranged from 0.035 to 0.054 . The average EAI volume was $2.66 \times 10^{3} \mathrm{~m}^{3}$ and ranged from $2.09 \times 10^{3}$ to $3.28 \times 10^{3} \mathrm{~m}^{3}$. The standard deviation of the EAI volume obtained from the three-point seeking calculations was $0.30 \times 10^{3} \mathrm{~m}^{3}$ (Fig. 5). The EAI distribution limits of the minimum, average close, and maximum EAI volumes in these cases were very similar to the observation results. However, the volumes differed depending on the length of the isoline major axes (Fig. 4c).

For the six four-point seeking calculations, the average axis angle was $345.9^{\circ}$, and maximum-minimum angle difference was $0.4^{\circ}$. The average ellipse aspect ratio was 0.043 and ranged from 0.035 to 0.052 . The average EAI volume was $2.63 \times 10^{3} \mathrm{~m}^{3}$ and ranged from $2.22 \times 10^{3}$ to $2.98 \times 10^{3} \mathrm{~m}^{3}$. The standard deviation of the EAI volume obtained from the four-point seeking calculations was $0.28 \times 10^{3} \mathrm{~m}^{3}$ (Fig. 5). The EAI distribution limits of the minimum, average close, and maximum EAI volumes in these cases were very similar to the observation results (Fig. 4d).

\section{Discussion and conclusion}

The distribution limit of the EAI analysis of the minimum value of the residual sum of the squares of the seeking with three and four points and the limit of the field observation almost correspond with the geometric calculation. The relationship between the area and thickness of the larger tephra is generally expressed as the square root of the isopach area (e.g., Pyle 1989; Sparks et al. 1992; Fierstein and Nathenson 1992). However, the plot of the thickness versus the square root of the isopach area of the tephra contain break-in-slopes depending on the differences in the Reynolds number based on the grain size, density, and eruption height (Rose 1993; Bonadonna et al. 1998). Intermediate- and low-Reynolds-number particles in the distal area are better described by the power-law behavior. This tendency is significant in the lower columns (Bonadonna et al. 1998). The ashfall of small Vulcanian eruptions can be approximated by the power-law function, because ashfall is composed of grains smaller than $2 \mathrm{~mm}$ (78 wt. \% in 2 and $3 \phi$ in Additional file 4: Fig. S1) deposited at a column height of less than $10 \mathrm{~km}$. The ashfall distribution of small eruptions from Sakurajima and other volcanoes exhibited approximately straight lines in the thickness versus isoline area (Tajima et al. 2013b; Oishi et al. 2018), suggesting power behavior. The EAI method approximated with a power of -1 may be well-distributed under Vulcanian or small magmatic ashfall conditions. Additionally, the creation of accretionary 


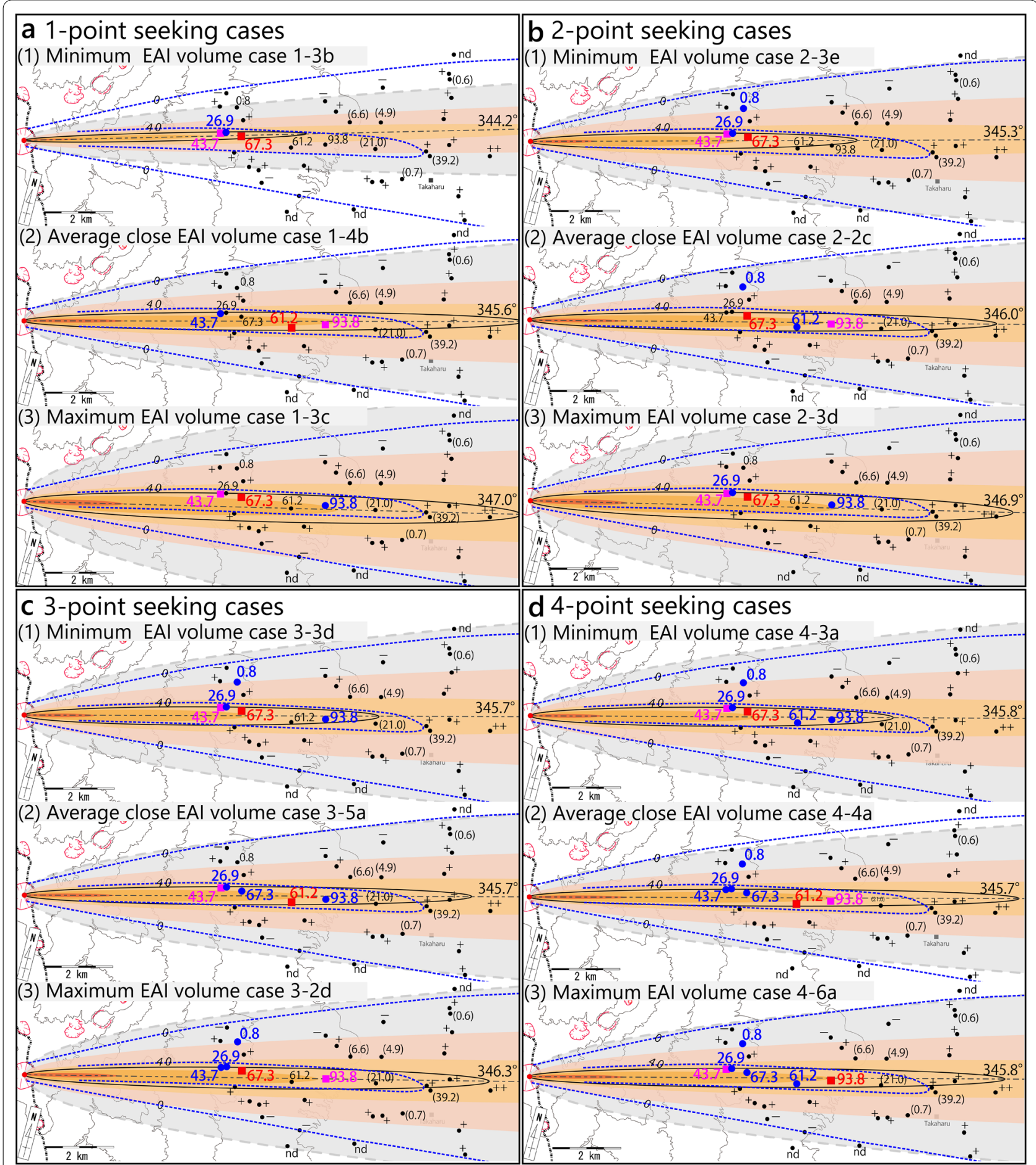

- observation point - calculation point 1 a calculation point $2 \bullet$ seeking point ++: abundant +: normal -: faint nd: not detected

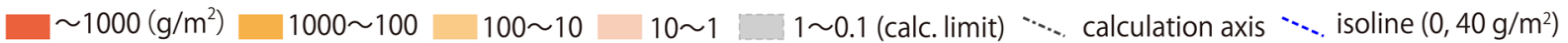

Fig. 4 Calculation results of the EAl distributions for the eruption at 15:34 on June 27. a The one-point seeking result of the minimum (1), average close (2), and maximum (3) EAI volume cases. b The two-point seeking result of the minimum (1), average close (2), and maximum (3) EAI volume cases. $\mathbf{c}$ The three-point seeking result of minimum (1), average close (2), and maximum (3) EAl volume cases. $\mathbf{d}$ The four-point seeking result of minimum (1), average close (2), and maximum (3) EAl volume cases. Numerical values are the amounts of ashfall $\left(\mathrm{g} / \mathrm{m}^{2}\right)$ to the points and axis angle $\left(^{\circ}\right)$ of the calculation. Blue dashed lines are the 0 and $40-\mathrm{g} / \mathrm{m}^{2}$ isolines obtained via the field survey, and the black line is the $40-\mathrm{g} / \mathrm{m}^{2}$ isoline obtained via the EAl calculation. Results of cases are shown in Additional file 3: Table S3 

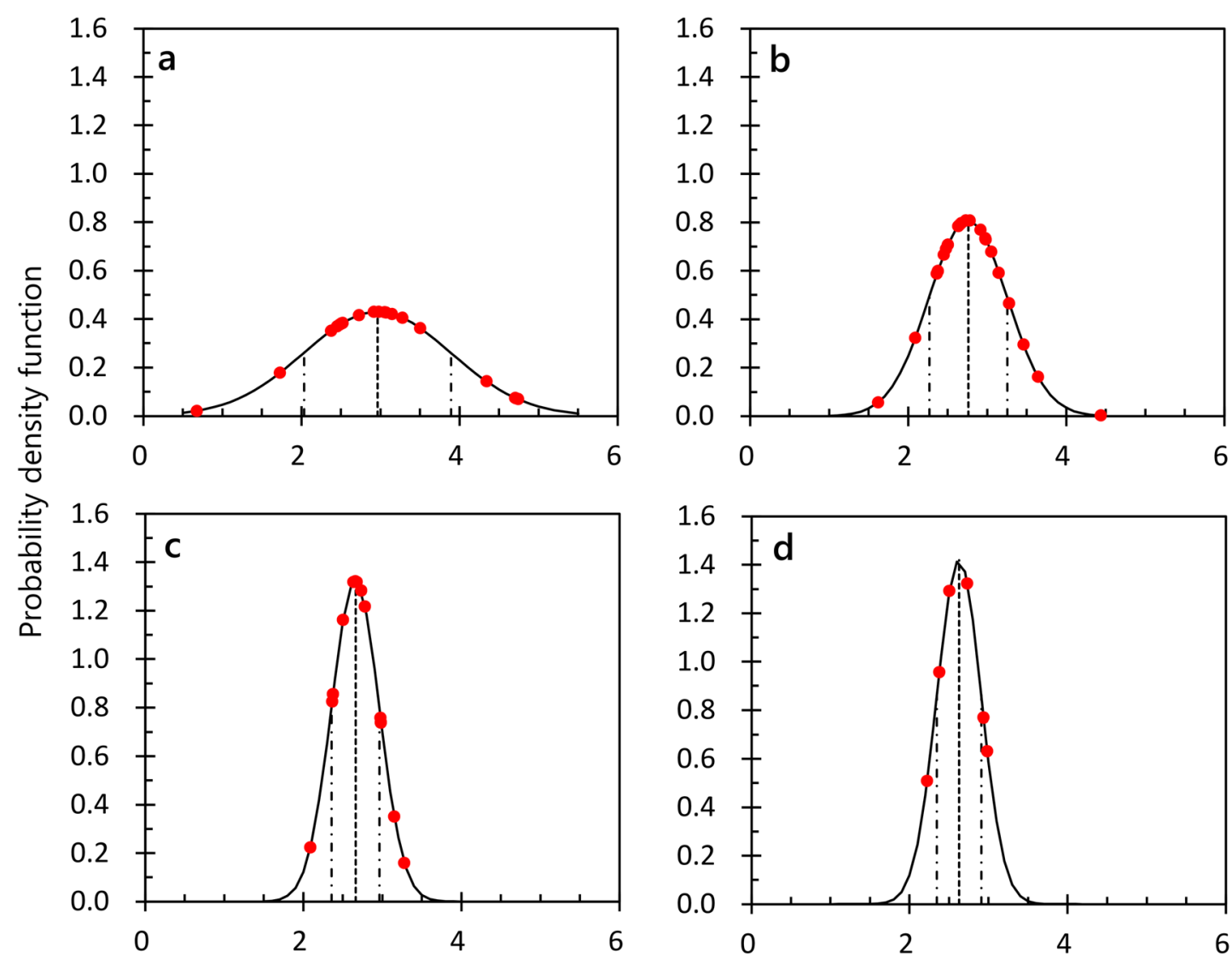

EAl volume of ashfall $\left(\times 10^{3} \mathrm{~m}^{3}\right)$

\begin{tabular}{c|ccc|ccc|cccc} 
Seeking & \multicolumn{3}{|c|}{ Axis angle $\left(^{\circ}\right)$} & \multicolumn{3}{c|}{ Aspect ratio } & \multicolumn{4}{c}{ EAl volume $\left(\times 10^{3} \mathrm{~m}^{3}\right)$} \\
cases & min. & ave. & max. & min. & ave. & max. & min. & ave. & max. & SD \\
\hline \hline a: 1 -point & 344.2 & 345.9 & 347.0 & 0.026 & 0.042 & 0.057 & 0.68 & 2.96 & 4.74 & 0.93 \\
b: 2-point & 345.3 & 345.9 & 346.9 & 0.034 & 0.043 & 0.056 & 1.62 & 2.76 & 4.44 & 0.49 \\
c: 3 -point & 345.6 & 345.8 & 346.3 & 0.035 & 0.043 & 0.054 & 2.09 & 2.66 & 3.28 & 0.30 \\
d: 4-point & 345.7 & 345.9 & 346.1 & 0.035 & 0.043 & 0.052 & 2.22 & 2.63 & 2.98 & 0.28
\end{tabular}

min.: minimum, ave.: average, max.: maximum, SD: Standard deviation

Fig. 5 Probability density function of the EAl volume with 1-4 seeking points. a Result of the one-point seeking cases. $\mathbf{b}$ Result of the two-point seeking cases. $\mathbf{c}$ Results of the three-point seeking cases. $\mathbf{d}$ Results of the four-point seeking cases. The table at the bottom denotes the EAl analysis results with different point-seeking numbers for the small eruption of Shinmoedake volcano on June 27, 2018

lapilli did not significantly impact power-law behavior in this case.

The standard deviations of the EAI volume decreased, and the average values slightly decreased when the number of seeking points increased from one to four (Fig. 5). The standard deviations and mean values of the seeking cases with three and four points were very similar. Therefore, three seeking points are desirable, and at least two seeking points are required when estimating the axis using only the seeking points. The EAI volume from the three-point seeking cases in this study was $2.66 \pm 0.60 \times 10^{3} \mathrm{~m}^{3}(2 \sigma)$. The volumes calculated by $V=12.2 \mathrm{TA}$ (Hayakawa 1985) and $V=3.69 \mathrm{TA}$ (Legros 2000) were $3.0 \times 10^{3}$ and $0.9 \times 10^{3} \mathrm{~m}^{3}$ based on the $40 \mathrm{~g} /$ $\mathrm{m}^{2}$ isoline, respectively. The average EAI volume of the three-point seeking case between these two volumes is acceptable. In another study, the EAI volume was between the exponential decay value calculated by the 
method of Fierstein and Nathenson (1992) and areathickness product calculation value at $V=12.2 \mathrm{TA}$ by Hayakawa (1985) (Tajima 2014). Therefore, the volume calculated by the EAI method is acceptable when compared to that of those methods. Thus, the EAI distribution (axis) determined using the minimum value of the residual sum of the squares could represent the observation results in the proximal area of the Vulcanian or small ashfall eruptions.

This study suggests that an ashfall distribution could be mechanically estimated within a certain accuracy by the EAI analysis. However, the EAI method is a simplified method and should be used with caution. For example, we know the tephra distribution is not always symmetrical across the axis and that the distribution axis may be biased. The eruption column may spread in a concentric circular shape around the crater with very weak wind. In these cases, ashfall distribution analysis by the EAI is possible, but the accuracy of the EAI volume may decrease. In small eruptions of the Sakurajima volcano, the high- and low-level wind directions are different. Therefore, even one eruption may produce ashfall in different directions (Poulidis et al. 2017, 2019). The selection of observation locations and analysis techniques must be improved in such conditions. In addition, it is necessary to calculate on multiple axes when the wind direction changes during an eruption, and many observed ashfall amount values are required to set them. Fortunately, the EAI calculation for a single eruption on June 27, 2018 could be performed in a simple case with a stable wind direction. Further research is needed to obtain cases that will be compared with other tephra volume assessment methods. This research case shows the potential of the EAI method to be applied to eruption analysis and tephra fields.

\section{Abbreviations}

EAI: Ellipse-approximated isopach; JST: Japan Standard Time.

\section{Supplementary Information}

The online version contains supplementary material available at https://doi. org/10.1186/s40623-021-01483-4.

Additional file 1: Table S1. Amounts of ashfall from the field observation. Additional file 2: Table S2. Ashfall deposit densities of Jan. 19, 2011, Shinmoedake eruption.

Additional file 3: Table S3. The EAI calculation result of the 1 to 4-point seeking cases.

Additional file 4: Figure S1. a The particle component of the deposit at Suigenchi $\left(61.2 \mathrm{~g} / \mathrm{m}^{2}\right)$; Bg: Black glass fragment, Gg: Gray glassy fragment, Rf: Red fragment, PI: Plagioclase, Px: Pyroxenes. $\mathbf{b}$ Grain-size distribution of the ashfall at Suigenchi $\left(61.2 \mathrm{~g} / \mathrm{m}^{2}\right)$.

\section{Acknowledgements}

The author is grateful to the anonymous reviewers and the editor Sonia Calvari and editor in chief Takeshi Sagiya for their helpful comments. The author thanks J. Okada for offering comments and member of Hinamori Auto Camp for helping with the ashfall information. Y. Shinozuka and A. Hasegawa of Nippon Koei for helping in the laboratory. This study was edited for English by Editage (www.editage.com).

\section{Authors' contributions}

YT designed the research, performed data processing, analysis, discussions and interpretation of the results, and wrote this paper. The author read and approved the final manuscript.

\section{Funding}

Not applicable.

\section{Availability of data and materials}

The data of the vent location used the website data of the Geospatial Information Authority of Japan (https://www.gsi.go.jp/BOUSAI/h30kirishima-index. $\mathrm{htm})$.

\section{Declarations}

\section{Competing interests}

The authors declare that they have no competing interests.

Received: 2 April 2021 Accepted: 13 July 2021

Published online: 30 July 2021

\section{References}

Aramaki S, Hayakawa Y (1982) Ash-fall during the April 26, 1982 Eruption of Asama Volcano. Bull Volcanol Soc Jpn 27:203-215. https://doi.org/10. 18940/kazanc.27.3_203 (in Japanese with English abstract)

Bonadonna C, Costa A (2012) Estimating the volume of tephra deposits: a new simple strategy. Geology 40:415-418. https://doi.org/10.1130/ G32769.1

Bonadonna C, Costa A (2013) Plume height, volume, and classification of explosive volcanic eruptions based on the Weibull function. Bull Volcanol 75:742. https://doi.org/10.1007/s00445-013-0742-1

Bonadonna C, Houghton BF (2005) Total grain-size distribution and volume of tephra-fall deposits. Bull Volcanol 67:441-456. https://doi.org/10.1007/ s00445-004-0386-2

Bonadonna C, Ernst GGJ, Sparks RSJ (1998) Thickness variations and volume estimates of tephra fall deposits: the importance of particle Reynolds number. J Volcanol Geotherm Res 81:173-187. https://doi.org/10.1016/ S0377-0273(98)00007-9

Bursik MI, Sparks RSJ, Gilbert JS, Carey SN (1992) Sedimentation of tephra by volcanic plumes: I. Theory and its comparison with a study of the Fogo A plinian deposit, Sao Miguel (Azores). Bull Volcanol 54:329-344. https:// doi.org/10.1007/BF00301486

Fierstein J, Nathenson M (1992) Another look at the calculation of fallout tephra volumes. Bull Volcanol 54:156-167. https://doi.org/10.1007/BF002 78005

Geospatial Information Authority of Japan (2013) https://vldb.gsi.go.jp/sokuc hi/surveycalc/surveycalc/bl2xyf.html. Accessed 1 Mar 2021 (in Japanese)

Geospatial Information Authority of Japan (2018) https://www.gsi.go.jp/BOUSAl/h30kirishima-index.htm. Accessed 1 Mar 2021 (in Japanese)

Hayakawa Y (1985) Pyroclastic geology of Towada volcano. Bull Earthq Res Inst Univ Tokyo 60:507-592

Imura R, Kobayashi T (1991) Eruptions of Shinmoedake Volcano, Kirishima Volcano Group, in the last 300 years. Bull Volcanol Soc Jpn 36:135-148. https://doi.org/10.18940/kazan.36.2_135 (in Japanese with English abstract)

Japan Meteorological Agency (2018) Volcanic activity of Kirishimayama Volcano -September 1, 2017-September 30, 2018. Rep Coordinat Committee for Predict Volcanic Erupt 131:280-350 ((in Japanese)) 
Kawase K (2011) A more concise method of calculation for the coordinate conversion between geographic and plane rectangular coordinates on the Gauss-Krüger projection. GSI Journal 121:109-124 ((in Japanese))

Legros F (2000) Minimum volume of a tephra fallout deposit estimated from a single isopach. J Volcanol Geotherm Res 96:25-32. https://doi.org/10. 1016/S0377-0273(99)00135-3

Nakada S, Nagai M, Kaneko T, Suzuki Y, Maeno F (2013) The outline of the 2011 eruption at Shinmoe-dake (Kirishima), Japan. Earth Planet Space 65:1. https://doi.org/10.5047/eps.2013.03.016

Oishi M, Nishiki K, Geshi N, Furukawa R, Ishizuka Y, Oikawa T, Yamamoto T, Nanayama F, Tanaka A, Hirota A, Miwa T, Miyabuchi Y (2018) Distribution and mass of tephra-fall deposits from volcanic eruptions of Sakurajima Volcano based on posteruption surveys. Bull Volcanol 80:42. https://doi. org/10.1007/s00445-018-1215-3

Poulidis AP, Takemi T, Iguchi M, Renfrew IA (2017) Orographic effects on the transport and deposition of volcanic ash: a case study of Mount Sakurajima, Japan. J Geophys Res Atmos. 122:9332-9350. https://doi.org/10. 1002/2017JD026595

Poulidis AP, Takemi T, Iguchi M (2019) Experimental high-resolution forecasting of volcanic ash hazard at Sakurajima, Japan. J Disaster Res 14:786-797. https://doi.org/10.20965/jdr.2019.p0786

Pyle DM (1989) The thickness, volume and grainsize of tephra fall deposits. Bull Volcanol 51:1-15. https://doi.org/10.1007/BF01086757

Rose WI (1993) Comment on "another look at the calculation of fallout tephra volumes" by Judy Fierstein and Manuel Nathenson. Bull Volcanol 55:372-374. https://doi.org/10.1007/BF00301148

Rose WI, Bonis S, Stoiber RE, Keller M, Bickford T (1973) Studies of volcanic ash from two recent Central American eruptions. Bull Volcanol 37:338-364. https://doi.org/10.1007/BF02597633

Sparks RSJ, Bursik MI, Ablay GJ, Thomas RME, Carey SN (1992) Sedimentation of tephra by volcanic plumes. Part 2: controls on thickness and grain-size variations of tephra fall deposits. Bull Volcanol 54:685-695. https://doi. org/10.1007/BF00430779

Sulpizio R (2005) Three empirical methods for the calculation of distal volume of tephra-fall deposits. JVolcanolo Geotherm Res 145:315-336. https:// doi.org/10.1016/j.jvolgeores.2005.03.001

Suzuki Y, Nagai M, Maeno F, Yasuda A, Hokanishi N, Shimano T, Ichihara M, Kaneko T, Nakada S (2013) Precursory activity and evolution of the 2011 eruption of Shinmoe-dake in Kirishima volcano-insights from ash samples. Earth Planet Space 65:11. https://doi.org/10.5047/eps.2013.02.004

Tajima Y (2014) Eruptive history and evaluation of Shinmoedake Volcano and Ebinokogen Volcanic Area of Kirishima Volcanoes for the past 10,000 years in Kyushu, Japan. Ph.D. thesis of Kagoshima University, p.205. (in Japanese with English abstract)

Tajima Y, Hayashi S, Yasuda A, Itoh H (2013a) Tephrostratigraphy and eruptive history of Shinmoedake volcano of the Kirishima volcanoes, Kyushu, Japan. Q Res 52:151-171. https://doi.org/10.4116/jaqua.52.151 (inJapanesewithEnglishabstract)

Tajima Y, Tamura K, Yamakoshi T, Tsune A, Tsurumoto S (2013b) Ellipse-approximated isopach maps for estimating ashfall volume at Sakurajima volcano. Bull Volcanol Soc Japan 58:291-306. https://doi.org/10.18940/kazan.58.1_ 291

Takarada S et al (2001) Volcanic ashfalls from the Usu 2000 eruption and situation at the source area. Bull Geol Surv Japan 52:167-179. https://doi.org/ 10.9795/bullgsj.52.167 (inJapanesewithEnglishabstract)

Takarada S, Hoshizumi H, Miyagi I, Nishimura Y, Miyabuchi Y, Miura D, Kawanabe Y (2002) Proximal deposits of the Usu 2000 eruption. Bull Geol Surv Japan 47:645-661. https://doi.org/10.18940/kazan.47.5_645 (in Japanese with English abstract)

Takarada S, Oikawa T, Furukawa R, Hoshizumi H, Itoh J, Geshi N, Miyagi I (2016) Estimation of total discharged mass from the phreatic eruption of Ontake Volcano, central Japan, on September 27, 2014. Earth Planet Sp 68:138. https://doi.org/10.1186/s40623-016-0511-4

Walker GPL (1980) The Taupo pumice: product of the most powerful known (ultraplinian) eruption? J Volcanol Geotherm Res 8:69-94. https://doi.org/ 10.1016/0377-0273(80)90008-6

Walker GPL (1981) Plinian eruptions and their products. Bull Volcanol 44:223-240. https://doi.org/10.1007/BF02600561

\section{Publisher's Note}

Springer Nature remains neutral with regard to jurisdictional claims in published maps and institutional affiliations.

\section{Submit your manuscript to a SpringerOpen ${ }^{\circ}$ journal and benefit from:}

- Convenient online submission

- Rigorous peer review

- Open access: articles freely available online

- High visibility within the field

- Retaining the copyright to your article

Submit your next manuscript at $\boldsymbol{\nabla}$ springeropen.com 